\title{
PERAN SEORANG GURU TERHADAP INOVASI PENDIDIKAN DI ERA MODERN
}

\author{
Akbar Hidayat \\ Email: akbarhidayat3203@gmail.com \\ Program Studi Pendidikan Sejarah Fakultas Keguruan dan Ilmu Pendidikan \\ Universitas Lambung Mangkurat \\ Banjarmasin
}

\begin{abstract}
Abstrak
Pendidikan tidak akan pernah diam, pendiidkan akan selalu berkembang dan mengalami perubahan, dalam proses perkembangan tersebut tentu harus ada dukungan dari orang- orang yang berwenang terhadapnya seperti pemerintah, masyarakat, dan sebagainya. Dengan ini agar terciptanya perubahan pendidikan diperlukannya sebuah inovasi dimana inovasi ini akan membawa pendidikan menuju perubahan yang lebih baik dan untuk menciptakan sebuah inovasi tersebut diperlukannya peran seorang guru yang diharapka mampu membawa anak didiknya untuk masuk kedalam sebuah perubahan karena gurulah yang menjadi langkah awal dalam berinovasi demi terciptanya sebuah perubahan pendidikan
\end{abstract}

\section{PENDAHULUAN}

Inovasi merupakan suatu perubahan atau pembaharuan yang diaman didalamnya terdapat ide maupun gagasan untuk menwujudkan suatu perubahan tersebut, Secara etimologi, inovasi berasal dari bahasa Latin, yaitu innovaation yang berarti pembaharuan dan perubahan. Kata kerjanya innovo, yang artinya memperbarui dan mengubah. Jadi, inovasi adalah perubahan baru menuju arah perbaikan dan berencana (tidak secara kebetulan). Dengan demikian, inovasi dapat diartikan usaha menemukan benda yang baru dengan jalan melakukan kegiatan (usaha) invention dan discovery. Dalam kaitan ini, Ibrahim (1989) mengatakan bahwa inovasi adalah penemuan yang dapat berupa sesuatu ide, barang, kejadian, metode yang diamati sebagai sesuatu hal yang baru bagi seseorang atau sekelompok orang (masyarakat). Inovasi dapat berupa hasil dari invention atau discovery. Inovasi dilakukan dengan tujuan tertentu atau untuk memecahkan masalah (Subandiyah, 1992: 80). 
Inovasi pendidikan adalah inovasi untuk memecahkan masalah dalam pendidikan. Inovasi pendidikan mencakup hal-hal yang berhubungan dengan komponen sistem pendidikan, baik dalam arti sempit, yaitu tingkat lembaga pendidikan, maupun arti luas, yaitu sistem pendidikan nasional. Inovasi dalam dunia pendidikan dapat berupa apa saja, produk ataupun sistem. Produk misalnya, seorang guru menciptakan media pembelajaran mock up untuk pembelajaran. Sistem misalnya, cara penyampaian materi di kelas dengan tanya jawab ataupun yang lainnya yang bersifat metode. Inovasi dapat dikreasikan sesuai pemanfaatannya, yang menciptakan hal baru, memudahkan dalam dunia pendidikan, serta mengarah pada kemajuan. Inovasi di sekolah, terjadi pada sistem sekolah yang meliputi komponen-komponan yang ada. Di antaranya adalah sistem pendidikan sekolah yang terdiri atas kurikulum, tata tertib, dan manajemen organisasi pusat sumber belajar. Selain itu, yang lebih penting adalah inovasi dilakukan pada sistem pembelajaran (yang berperan di dalamnya adalah guru) karena secara langsung yang melakukan pembelajaran di kelas ialah guru. Keberhasilan pembelajaran sebagian besar tanggung jawab guru (rusdiana, 2014:46).

\section{PERAN GURU SEBAGAI SEBUAH PROFESI}

Agar dunia pendidikan dapat lebih inovatif diperlukan guru yang berkompeten dan memiliki kreativitas yang tinggi. Guru harus mempunyai cara menyampaikan pembelajaran agar belajar itu menarik dan mudah dimengerti. Peran guru pada inovasi di sekolah tidak terlepas dari tatanan pembelajaran yang dilakukan di kelas. Guru harus tetap memerhatikan sejumlah kepentingan siswa, di samping harus memerhatikan suatu tindakan inovasinya. Guru sebagai ujung tombak dalam pelaksanaan pendidikan merupakan pihak yang sangat berpengaruh dalam proses belajar mengajar. Kepiawaian dan kewibawaan guru sangat menentukan kelangsungan proses belajar mengajar di kelas maupun efeknya di luar kelas. Guru harus pandai membawa siswanya pada tujuan yang hendak dicapai. Oleh karena itu guru harus inovarif terhadap pendidikan hal ini sesuai dengan hak seorang guru Dalam menjalankan tugas dan profesinya, guru memiliki hak dan kewajiban yang harus dilaksanakan dan diperhatikan. Hak guru berarti suatu yang harus didapatkan olehnya setelah ia melaksanakan sejumlah kewajibannya sebagai guru. Kewajiban guru adalah sesuatu yang harus patut dilaksanakan oleh guru dalam menjalankan profesinya. Hak dan kewajiban guru 
sebagai pendidik diatur di semua peraturan perundang-undangan yang berkaitan dengan pendidikan (Susanto, 2020:36).

bentuk inovasi yang dapat dilakukan guru dalam berinovasi di era teknologi informasi sekarang yaitu seperti penggunaan media dalam proses pembelajaran, memanfaatkan smartphone untuk belajar dan media lainnya yang dapat membantu para siswa menjalankan pembelajaran dengan baik, media disini merupaka sebuah inovasi sebagai alat penghantar informasi kepada siswa dalam proses pembelajarannya, Dalam konteks pembelajaran, media diartikan sebagai alat bantu mengajar, Ini menandakan bahwa segala jenis alat elektronik maupun non elektronik disebut media asal mampu menyampaikan informasi pembelajaran (Susanto, 2021:66).

\section{GURU INDONESIA DAN TANTANGAN PROFESIONALISME}

Guru merupakan satu di antara profesi di bidang pendidikan. Dalam Undang-Undang No. 14 Tahun 2005, dikatakan guru adalah pendidik profesional dengan tugas utama mendidik, mengajar, membimbing, mengarahkan, melatih, menilai, dan mengevaluasi peserta didik pada pendidikan anak usia dini jalur pendidikan formal, pendidikan dasar, dan pendidikan menengah. Guru dapat diartikan sebagai orang yang tugasnya terkait dengan upaya mencerdaskan kehidupan bangsa dalam semua aspeknya, baik spiritual dan emosional, intelektual, fisikal, maupun aspek lainnya. (Susanto, 2020:36). Dengan berkembangnya teknologi informasi sekarang seorang guru tidak lagi mengajar seperti jaman dahulu dimana guru mengajar hanya sekedar mengajar melalui buku dan hanya sedikit media yang diberikan, beda halnya jaman sekarang diaman teknologi informasi sudah berkembang begitu pesat dan dampaknya pada pendidikan ini adalah memudahkan seorang guru untuk memanfaatkan teknologi dan memudahkan para siswa untuk menggali berbagai informasi melalui berbagai media ini. Media dapat menumbuhkan sikap positif siswa terhadap materi dan proses belajar. Proses pembelajaran menjadi lebih menarik apabila menggunakan media yang tepat sehingga siswa termotifasi untuk mencintai ilmu pengetahuan yang sedang dipelajarinya. Dan media juga banyak sekali macamnya seperti media visual, media audio dan media audio visual. 
Kemudian inovasi yang dilakukan guru dalam proses pendidikan terhadap teknologi informasi juga harus dilakukan mengingat hal tersebut dapat menjadi sebuah tujuan setiap guru karena yang sudah kita ketahui adalah guru harus memiliki sebuah inovasi dalam proses pembelajaran dan inovasi tersebut bisa berupa teknologi dan yang lainnya. Di era sekarang smarphone dan computer merupakan alat cerdas yang dimiliki setiap orang karena dengan alat ini kita mampu mengakses informasi apapun yang kita inginkan tanpa batasan, kedua alat ini juga dimanfaatkan untuk membantu siswa menemukan dan merumuskan pengetahuannya melalui interaksi dan eksplorasi sumbersumber belajar berbasis teknologi informasi. Selain itu, pemanfaatan teknologi dalam pembelajaran juga mendukung teori socio-constructivism, yakni siswa memperoleh pengalaman belajar secara bersama-sama dengan siswa lain atau melalui interaksi dengan para pakar dengan media komunikasi berbasis teknologi. Perkembangan terkini adalah pemanfaatan teknologi secara terpadu di dalam pembelajaran yang memadukan berbagai keterampilan dan fungsi teknologi dalam proses belajar mengajar. Adapun pembelajaran melalui internet yang memanfaatkan teknologi informasi ini antara lain bimbingan belajar online seperti Quipper, Ruangguru, dan Zenius serta platform Edmodo dan Google Classroom. Pembelajaran biasanya berlangsung dengan metode face to face atau sistem langsung. Namun dengan berkembangnya teknologi sekarang ini, belajar tidak selalu harus berhadapan langsung antara guru dan murid. Belajar online bisa dibilang lebih efisien secara waktu dan tempat, karena dapat dilakukan di waktu senggang dan di manapun, selama koneksi internet lancar. Di Indonesia, banyak sekali website yang menyediakan atau menawarkan jasa belajar online. Ada beberapa di antaranya yakni Ruangguru, Quipper, dan Zenius. Semua website tersebut memiliki keunggulan pada sektor produk dan keefisienan cara belajarnya. Ruangguru, Quipper, dan Zenius memiliki metode belajar, cara belajar, dan sistem belajar yang berbeda. Itulah pentingnya teknologi yang digunakan oleh guru dalam proses pembelajaran.

\section{SIMPULAN}

inovasi merupakan sebuah ide maupun gagasan dimana inovasi ini dapat menciptakan suatu perubahan dalam hal apapun, dalam pendidikan inovasi ini sangat dibutuhkan karena dengan inovasi ini mampu memperbaharui proses pendidikan yang ada di Indonesia agar tidak 
menjadi sebuah pendidikan yang pasif atau tidak ada perkembangannya sama sekali, dan peran guru dalam inovasi pendidikan ini sangat penting karena dengan guru mampu membawa sebuah perubahan dalam proses pembelajaran melalui inovasi yang dapat meningkatkan kualitas belajar dan berkembang serta mampu memecahkan permasalahan pendidikan yang dialami dimasa sekarang dan berkat teknologi informasi ini seorang guru menjadi mudah dalam memberikan pengajaran kepada anak didiknya karena sebuah teknologi sudah mampu menjalankan itu semua tinggal bagaimana seorang guru apakah mampu untuk melakukan pengaplikasian terhadap teknologi yang sudah ada di era sekarang jika hal tersebut mampu maka sebuah inovasi pendidikan akan berjalan mengikuti perkembangan jaman tanpa adanya permasalahn lagi pada pendidikan dan terciptalah sebuah inovasi dari peran seorang guru.

\section{REFERENSI}

Anis, M. Z. A., Putro, H. P. N., Susanto, H., \& Hastuti, K. P. (2020). Historical Thinking Model in Achieving Cognitive Dimension of Indonesian History Learning. PalArch's Journal of Archaeology of Egypt/Egyptology, 17(7), 7894-7906.

Anis, M. Z. A., Susanto, H., \& Mardiani, F. (2021, February). Analysis of the Effectiveness of MPBH: The Mains of Mandai as a Saving Food in Banjarmasin Community. In The 2nd International Conference on Social Sciences Education (ICSSE 2020) (pp. 89-94). Atlantis Press.

Efendi, I., Prawitasari, M., \& Susanto, H. (2021). Implementasi Penilaian Pembelajaran Pada Kurikulum 2013 Mata Pelajaran Sejarah. Prabayaksa: Journal of History Education, 1(1), 21-25.

Susanto, H. (2020). Profesi Keguruan. Banjarmasin: FKIP Universitas Lambung Mangkurat.

Susanto, H., \& Akmal, H. (2018). Efektivitas Penggunaan Aplikasi Pembelajaran Berbasis Mobile Smartphone Sebagai Media Pengenalan Sejarah Lokal Masa Revolusi Fisik Di Kalimantan Selatan Pada Siswa Sekolah Menengah Atas. HISTORIA: Jurnal Program Studi Pendidikan Sejarah, 6(2), 197-206.

Susanto, H., Irmawati, I., Akmal, H., \& Abbas, E. W. (2021). Media Film Dokumenter Masuknya Islam Ke Nusantara dan Pengaruhnya Terhadap Keterampilan Berpikir Kritis Siswa. HISTORIA: Jurnal Program Studi Pendidikan Sejarah, 9(1). 
Ibrahim. (1988). Inovasi Pendidikan. Jakarta: Proyek Pengembangan Lembaga Pendidikan Tenaga Kependidikan, Ditjen Dikti Depdikbud.

Rusdiana. (2014). konsep inovasi pendidikan. bandung: CV. PUSTAKA SETIA.

Subandijah. (1993). Pengembangan dan Inovasi Kurikulum. Jakarta: Raja Grafindo Persada. 